\title{
Evaluating Market Power in the ZimbabWean BANKING SECTOR
}

\author{
Sanderson Abel* \\ Nelson Mandela Metropolitan University
}

Received: April 2016

\author{
Pierre le Roux* \\ Nelson Mandela Metropolitan University
}

Accepted: November 2016

\begin{abstract}
The study evaluates the nature of market structure, and the degree and determinants of market power in the Zimbabwean banking sector during the period 2009-2014. The study employs the Lerner Index approach method to assess the market power of banks. The Lerner Index approach assists in measuring the extent to which a bank has market power to set its price above marginal cost. The study results established that the banking sector operates under monopolistic competition, confirming that banks possess some market power in pricing their products. This is a result of the nature of products sold by the banking sector, which are differentiated but close substitutes. The study found that the market power of banks increased during the period and was derailed by the memorandum of association which was signed between banks and the central bank. The study established that market power is determined by capital adequacy, non-performing loans, liquidity risk, cost income ratio, economic growth, and regulatory interventions. The study recommends that the government should ensure that it puts in place measures that enhance economic growth and should desist from interfering with the operations of market forces.
\end{abstract}

Keywords

Lerner Index, Market Power, Monopolistic, Panel Regression, Zimbabwe

*Mr S Abel is a PhD student in the Department of Economics at the Nelson Mandela Metropolitan University, Port Elizabeth, South Africa. [abelsza.mwale@gmail.com]

\#Prof $\mathbf{P}$ le Roux is professor of $\varepsilon$ conomics in the Department of Economics at the Nelson Mandela Metropolitan University, Port Elizabeth, South Africa. 


\section{INTRODUCTION}

The market power of a bank gives an indication of the level of competition in the banking sector. It describes the extent to which a bank can set its price above marginal cost. Market power in the banking sector is associated with social loss emanating from higher prices and restricted output. Hicks (1935) terms it the quiet life hypothesis. The hypothesis explains the relationship between market power and efficiency. Hicks argues that monopoly power rules out competition among firms - hence allows managers to enjoy a quiet life. This means managers have no incentive to be innovative, which reduces efficiency.

Monopoly power gives managers the freedom to seize monopoly rents through unrestricted costs or without exerting their efforts. Berger and Hannan (1998) summarised the main drawbacks of market power. Firstly, it allows banks to price their products above competitive prices, which discourages managers from maintaining costs at reasonable levels. Secondly, it allows managers to pursue objectives other than profit maximisation. Thirdly, managers may actually deploy resources towards the maintenance of market power. Lastly, exploitation of market power may allow the persistence of inefficient managers, leading to increased cost inefficiency.

The exercise of market power reduces the incentives for managers to maximise operating efficiency, as competitive pressure is reduced. Market power also reduces market discipline, removing the signals that normally force changes in management. This leads to the retention of managers in positions in which they do not possess a competitive edge. Pagano (1993) posits that market power allows banks to charge higher loan rates and compensate savers with lower deposit rates, which reduces the equilibrium quantities of funds available for credit, thus reducing the growth potential of economies. Similarly, Guzman (2000) suggests that market power has a negative effect on capital accumulation and leads to inefficient outcomes, as it involves excessive monitoring. Guzman (2000) further suggests that monopoly power increases the loan rates, which increases the likelihood of default as a result of moral hazard. This then forces banks with monopoly power to sustain higher costs in monitoring entrepreneurs, thus diverting resources that could otherwise be available for lending. Berger (2009) posits that those banks with greater market power have lower risk. The argument that an increase in the bank's market power leads to a decline in the bank's credit risk is supported by Jimenez et al. (2010).

There are a number of studies that have attempted to measure banking sector competition using the Lerner Index approach (Fernández de Guevara, Maudos \& Pérez 2005, Berger, Klapper \& TurkAriss 2009, and Fungačova et al. 2010). The different studies have produced different results that have at times been contradictory, hence showing that the banking sector is not a homogeneous group. This makes the case for more studies to further enrich the literature - hence the current study on the Zimbabwean banking sector, which is taken as the laboratory. There is currently no similar study that has been undertaken in Zimbabwe which the authors are aware of. The study is of importance to policymakers, since the identification of the market structure and the determinants of the market structure helps in the development of policy-relevant interventions in the sector. The study contributes to the literature by examining the Zimbabwean banking sector after the country adopted a multicurrency system.

The objective of the study is to ascertain the market structure and the determinants of market power in the Zimbabwean banking sector. The Zimbabwean banking sector is of interest because banks have been accused of excessive profiteering through overpricing their products. The interest rates spreads, fees and other charges have been presumed to be high (Reserve Bank of Zimbabwe 2013). From an economic perspective this means banks have been using their market 
power to influence prices. This led to the monetary authorities' intervention in 2013 through instituting a memorandum of understanding ( $\mathrm{MoU}$ ) between the central bank and the other banks. The MoU gave guidance in the setting of the interest rates and bank charges (Reserve Bank of Zimbabwe 2013). The central bank further issued a new directive capping interest rates in 2015 (Reserve Bank of Zimbabwe 2015). The question that becomes paramount is that are banks exploiting their market power to charge higher interest rates and bank charges, or the banks are simply using the market forces to determine the pricing.

\section{STYLISED FACTS ABOUT THE ZIMBABWEAN BANKING SECTOR}

The banking sector in Zimbabwe has undergone four distinct phases since the attainment of independence: post-independence (1980-1990), the reform period (1991-1999), the crisis period (2000-2008) and the multicurrency period (2009-2014). During the post-independence period (1980-1990) the banking sector was heavily regulated and followed a segmented market approach. The sector was oligopolistic in nature and was dominated by a few foreign banks with limited competition (Chipika \& Malaba 2011). The sector was characterised by barriers to entry. This allowed the banks to form cartels to fix interest rates. There were a few notable foreign banks, namely Barclays, Standard Bank and First Merchant Bank among others (Kanyenze et al. 2011). Pricing of banking products was determined by the banks, and government determined the minimum lending rates, which is typical of repressive financial regulatory regimes (Mabika 2001).

The financial sector was liberalised in 1991 so as to allow the free operation of market forces to foster competition and efficiency. Regulatory barriers were lifted and new entrants were allowed into the banking sector, leading to the licensing of the first Zimbabwean indigenous bank, the United Merchant Bank, in 1997 (Mumvuma et al. 2003). Subsequently the number of banks in the country increased from ten in the post-independence period to thirty in 1999 (Mumvuma et al. 2003). The liberalisation of the banking sector did not enhance competition. There was no change in terms of product offering on the market as banks continued offering generic products such as deposit mobilisation and lending to established corporates (Kanyenze et al. 2011).

The country experienced an economic crisis during the period 2000-2008. The number of banking institutions increased to forty-three by 2003 (Kanyenze et al. 2011). There were thirteen bank failures registered as a result of liquidity challenges, corporate governance challenges and inadequate risk management. Banks were involved in insider dealing and an abuse of central bank liquidity advances. In response to these complications, the central bank stopped the lender of last resort function and instituted a raft of measures to control banking sector challenges (Makoni 2010). The banking sector was profitable during this period, with an average return on assets and equity of $11.6 \%$ and $65.2 \%$ respectively.

As a measure to restore macroeconomic stability, the government abandoned the local currency and adopted foreign currencies as legal tender in 2009. Since the banking sector has transformed there have been both negative and positive developments in the banking sector.

Economic stability nurtured an environment that improved financial intermediation. Financial stability improved the confidence in the financial sector, leading to increased bank deposits and lending. 


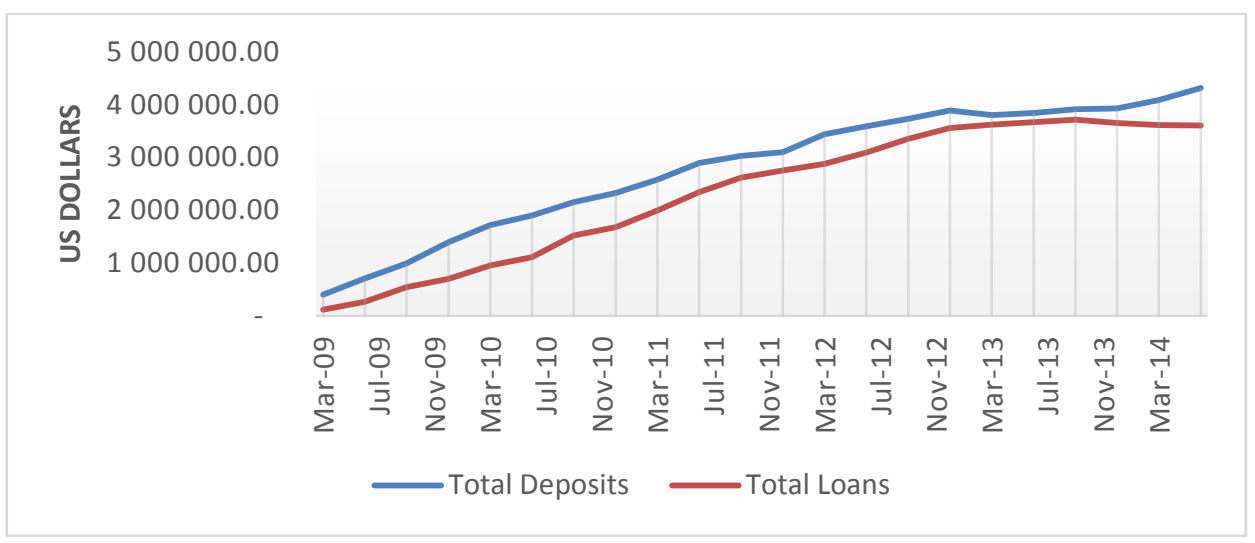

\section{FIGURE 1: Total loans and total deposits}

Source: Reserve Bank of Zimbabwe (2009 to 2014)

The total amount of deposits in the banking sector increased from US\$382 200 in February 2009 to US\$1 400000 in December 2009 (FIGURE 1). The growth trajectory in deposits continued in the subsequent years to reach US\$4 320000 by August 2014. There has been an increase in confidence in the banking sector by the banking public since 2009, which saw the public increase their use of banks. The increase in deposits was a result of increased salaries as well as increased production in industry. The various incentives that banks have been offering, including the increased product offering, have also assisted people to use the banking sector. Most individuals in the formal sector were forced to open bank accounts so as to get loans, as banks went on a drive to offer salarybased loans. Banks also have been involved in negotiating offshore lines of credit, which has significantly increased their resources. Despite the increase in deposits, the growth rate in the total deposits started to decline in 2013.

Corresponding to the increase in the deposits, the total amount of loans and advances also increased during the period 2009 to 2014. In February 2009, the total amount of the loans in the banking sector amounted to US\$103 100, which increased to US\$700 000 in December 2009. This amount further increased to US\$3 726670 in August 2014 (RBZ 2014). Competition for clients by the banks saw them increase their supply of loans and advances to both corporates and individuals. On the other hand there has been increased demand for working capital and capital expenditure by the productive sector. Individuals also increased demand for personal loans. Banks responded by increasing salary-based loans, which constituted about $25 \%$ of the banks' loan books.

TABLE 1: Financial Indicators 2008-2012

\begin{tabular}{llllll}
\hline & 2008 & 2009 & 2010 & 2011 & 2012 \\
\hline Market share of top four banks & 0.97 & 0.56 & 0.48 & 0.43 & 0.45 \\
Return on assets & 0.25 & 0.01 & 0.02 & 0.02 & 0.02 \\
Return on equity & 0.28 & 0.03 & 0.07 & 0.15 & 0.09 \\
Interest margin/gross income & 0.22 & 0.14 & 0.24 & 0.35 & 0.35 \\
\hline
\end{tabular}

Source: Authors' analysis 
The market share of the top four banks declined from $97 \%$ in 2009 to $45 \%$ in 2012 (TABLE 1 ). Before 2009 the banking sector experienced a flight-to-quality situation, where the banking public had moved their deposits to the few perceived strong banks. These banks were presumed to be safer and stronger. The high market share prior to 2009 was a result of loss of confidence by the banking public in local banks as a result of bank failures among local banks. These bank failures were mostly a result of poor corporate governance, insolvency and liquidity challenges. Since 2009 , the market share of the top four banks has declined significantly to $45 \%$ by 2012 . Banks have been involved in aggressive promotions and marketing so as to increase their market shares.

The interest rate margin, which approximates banking sector efficiency, improved over time (TABLE 1). The interest margin accounted for a growing share of gross income from $12 \%$ in 2004 to $35 \%$ in 2012 . The increase in the interest margin as a share of gross income shows that the players in the banking sector have been increasingly relying on interest income as a source of revenue.

The return on equity increased from $3 \%$ in 2009 to $9 \%$ in 2012 (TABLE 1). Post 2008, the central bank has increased its supervision and monitoring of financial institutions in order to avoid the repetition of the disorder that characterised the banking sector during the crisis period. The profitability indicators show that the banking sector was profitable during the study period.

The banking sector was also affected by poor-quality assets during the period 2009-14. The level of non-performing loans (NPLs) increased from 1.8\% in Feb 2009 to 20.1\% by September 2014 (FIGURE 2).

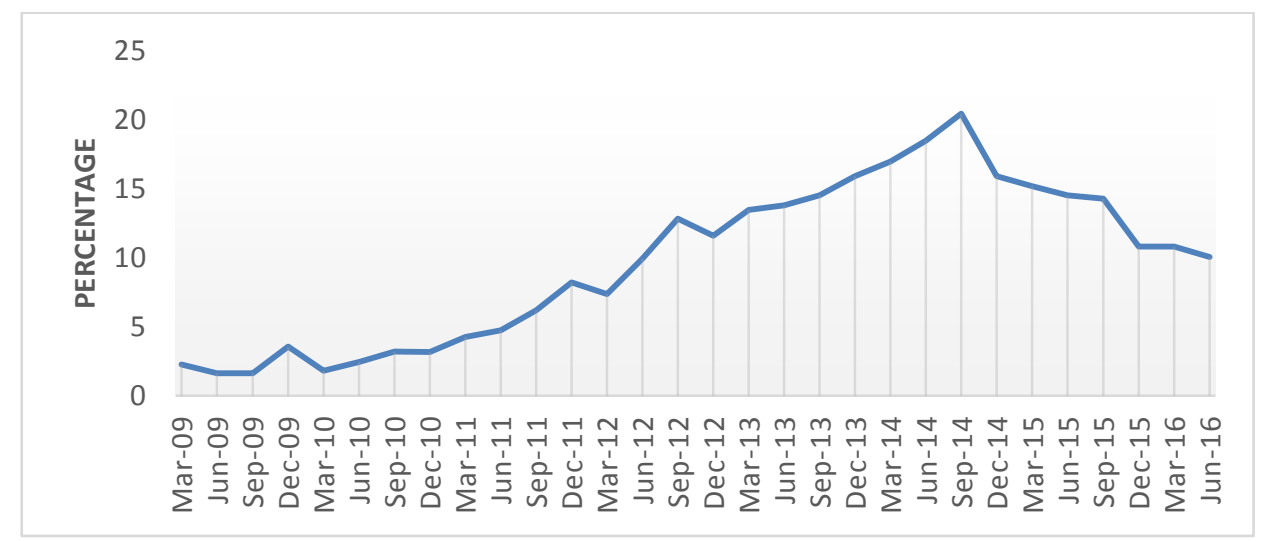

FIGURE 2: Trends in Non-Performing Loans, 2009-2016

Source: Authors' analysis

The growth in NPLs limited the capacity of banks to expand financial intermediation. The increase in NPLs led to the problem of disintermediation, where the banks had to cut down on their lending and requested borrowers to pledge collateral even for small loans. Non-performing loans have adversely affected the performance of the banking sector through increased provisioning and a reduction in profitability. The central bank attributed the increasing non-performing loans to the high interest rate that banks have been charging on the loans.

The number of operating banking institutions declined from 28 in December 2008 to 20 by mid2014. The decline in the number of banks resulted from the collapse of some of the banks and the consolidations and mergers that took place in an effort to meet the stringent regulatory capital 
requirements. The failure of the banks was mostly due to poor corporate governance, insolvency and imprudent lending activities (RBZ 2014).

The market concentration measured by the Herfindahl-Hirschman Index (HHI) for deposits increased from 1,300 in 2009 to 1,420 as at 31 December 2014. This means that the deposit concentration increased in the banking sector during the study period. The highest level of the $\mathrm{HHI}$ during the period was experienced in 2014, implying that there has been increased market power in the banking sector.

Perceiving that the banking sector was profiteering from excessive interest rates and bank charges while paying little on deposits, the government instituted a Memorandum of Understanding (MoU) between the central bank and other banks. The introduction of the (MoU) between the central bank and the other banks in February 2013 introduced price controls in the banking sector, since it outlined the pricing structure of the various banking products. It outlined the limits on bank charges and interest rates on various banking products. Some of the features of the MoU were the requirements to reveal the amount of interest on the 14-day call or fixed deposit accounts. Banks were required to ensure that any term deposit by individual customers of US\$1 000 would be offered an interest rate of no less than $4 \%$ when held over a period of at least 30 days. All banking institutions were supposed to pay interest on savings accounts, provided that each participating banking institution was at liberty to create its own variety of savings accounts. The MoU required lending rates to be set at a rate not exceeding 12.5 percentage points above the participating financial institution's weighted cost of funds. In cases where a loan or other advance made to a customer did not fall within the agreed parameters, as set out in the loan agreement, the participating institution was supposed to charge a penalty interest not exceeding $10 \%$ per annum. This was supposed to be exclusive of collection costs and legal costs on the legal practitioner-client scale.

The review of the banking sector in this section has shown that there has been a decline in the market share of the top four banks, an increase in deposit concentration, an increase in interest margins and an intervention by the central bank in the form of control pricing in the banking sector. This motivates the study to evaluate the market power of the banking sector and ascertain the drivers of market power in Zimbabwe during the period 2009-2014.

\section{LITERATURE REVIEW}

\subsection{Theoretical literature review}

There are three main empirical methods of measuring competition / market power that have been discussed in the literature. These are the traditional Industrial Organisation, New Structural and the New Empirical Industrial Organisation (NEIO) approaches (Claessans 2009; Leon 2014). The traditional methods or structural approaches are mostly premised on Structure-ConductPerformance (SCP) analyses. The SCP assumes that the likelihood of collusion increases with market concentration. The method infers competition from the market structures (Leon 2014). On the other hand, the new structural measures rely on regulatory indicators to measure the degree of contestability. The method is based on regulatory variables such as entry requirements, informal and formal barriers to entry by both domestic and foreign banks and activity restrictions, among other things (Leon 2014). 
The New Empirical Industrial Organisation (NEIO) methods depart from the traditional methods by measuring competition from the firms conduct directly, rather than inferring competition from market shares or market structure. The NEIO approaches are based on optimisation models from which are derived indicators of competition or market power, and these include the Lerner Index, the Panzar and Ross H-statistic (1982, 1987), the conjectural variation parameters (Bresnaham 1982; Lau 1982) and the Boone indicator (Boone 2000, 2001, 2004).

The Lerner Index (1934) is one of the NEIO methods that have been used in empirical determination of market power in the banking sector (Fernández de Guevara, Maudos \& Pérez 2005, Berger, Klapper \& Turk-Ariss 2009, and Fungačova et al. 2010). The Lerner Index is a relative mark-up of price over marginal cost (Lerner 1934). Coccorese (2009) posits that the Lerner Index is a true reflection of the banks' degree of market power, because it represents the behavioural departure from monopoly and perfect competition. The index also recognises the need for endogenised market structures in testing market power (Delis, Staikouras \& Varlagas 2008). The market power of a firm is identified by the divergence between the firm's price and its marginal cost. The price and marginal cost should be equal in perfect competition, but will diverge in less competitive environments. A bigger the difference between price and marginal cost the greater the monopoly power (Fernandez de Guevara et al. 2005, Berger et al. 2009 and Fungačova et al. 2010). The Lerner Index can be calculated at each point in time (Demirguc-Kunt \& Peria 2010).

\subsection{Empirical literature review}

A number of studies have applied the Lerner Index methodology to determine the degree of competition or market power in the banking sector. In a study of the Czech credit market, Pruteanu-Podpiera (2007) estimated the Lerner Index for the period 1995-2005. The Lerner Index was found to be 0.374 , rejecting the notion that the Czech credit market was either monopolistic or perfectly competitive over the period analysed. The results showed that there was a decrease in competition between 1995-1998 and 1999-2000. Competition increased thereafter up to 2002. The period 2003-2004 saw a decrease in competition, with a slight revival in 2005. Fungacova et al. (2010) examined the determinants of market power using the Lerner Index in the Russian banking sector over the period 2001-2007. The study found that the banking sector in Russia improved slightly over the period. The results showed that market power in Russia was determined by bank size, risk and market concentration. Anzoategui, Peria and Melecky (2012) examined competition in the Russian banking sector and found that greater market power was held by larger and state-owned banks compared to other banks. The results revealed that competition in the Russian banking sector was negatively affected by bank concentration, while financial and economic development positively influenced competition. Employing the Lerner Index and the Logit analysis, Fungacova and Weill (2009) studied the fragility of Russian banks over the period 2001-2007. The results found that the Russian banking sector supported the competition fragility hypothesis, implying that more intense competition compromises financial stability. Fernandez de Guevara et al. (2005) studied the evolution of market power in the European Union banking sector using the Lerner Index. The study found that there was no increase in the degree of competition within the European Union. The results further revealed that bank size, risk, efficiency and economic cycles are significantly related to the market power of European banks. Employing the Lerner Index, Fernandez de Guevara and Maudos (2007) investigated market power in the Spanish banking industry for the period 1986-2002. The study showed that there was an increase in market power starting from the mid-1990s. The results revealed that market power was determined by bank size, efficiency and specification in the Spanish banking sector. 
In a study of eleven European Union countries, Liu et al. (2010) studied the competitive conditions during the period 2000-2008. The study was intended to ascertain the competition-stability relationship in banking. It was found that there was a non-linear relationship between competition and stability in European banking. The study further found that marginal effects exist in highly competitive markets, where increased competition reduces loan interest payments and the provisions for non-performing loans. A number of studies have shown that restricting foreign bank participation in the local market and restricting the scope of banking activities reduce the degree of competition (Delis 2012, Gelos and Roldos 2004, Hasan and Marton 2003, DemirgucKunt et al. 2004). Competition is enhanced by liberal policies toward foreign bank involvement. Banking sectors which are not subject to restrictions on bank entry and scope of activities are competitive, more stable and efficient (Hasan \& Marton 2003; Claessens \& Laeven 2004). Abdul Majid and Sofian (2008) studied the level of competition and the structure of the Islamic banking industry in Malaysia and found that the Malaysian banking sector was neither a monopoly market nor perfectly competitive. The results revealed that the Islamic banks in Malaysia operated under a system of monopolistic competition. Korsah, Nyarko and Tagoe (2001) measured the intensity of bank competition in the Ghana banking sector after the implementation of economic reforms in the form of Financial Structural Adjustment Programmes (FINSAP). The results showed that there was an increase in competition in Ghana's banking system as a result of the economic reforms, and the banking sector was oligopolistic in nature, which explained the profitability of the sector. Fu and Heffernan (2009) investigated the relationship between market structure and performance in the Chinese banking system after reforms in the financial sector. They found that $x$-efficiency significantly decreased and the majority of the banks operated below the levels of efficiencies of effective scale.

\section{METHODOLOGY}

The study employs the Lerner Index to measure the degree of market power in the banking sector. There are a number of advantages of the Lerner Index over other methods such as the HHI (Bulow \& Klemperer 2002; Amir 2010; Boone 2008; Turk Ariss 2010 and Schaeck and Cihák 2010). It is bankspecific and changes over time, making comparison of market power among banks over time possible. The method is simpler, easier to interpret and does not pose stringent data requirements. The Lerner Index offers the possibility of studying the evolution of bank pricing behaviour over time, while it does not depend on the definition of the relevant market. The model further allows market power to be measured separately for the different banking markets by geographic location or by products.

The Lerner Index represents the extent to which a particular bank has market power to set its price above marginal cost. The marginal cost is derived from the cost function. A trans-log cost function is computed for each year through the introduction of fixed effects for banks. The assumption of linear homogeneity in input prices is imposed by normalising total costs and input prices by one input price.

The cost function is specified following the works of Pruteanu-Podpiera, Weill and Shobert (2008):

$$
\begin{aligned}
\ln \left[\frac{T C}{w_{3}}\right]=\alpha_{0}+ & \alpha_{1} \ln y+\frac{1}{2} \alpha_{2}(\ln y)^{2}+\alpha_{3} \ln \left(\frac{w_{1}}{w_{3}}\right)+\alpha_{4} \ln \left(\frac{w_{2}}{w_{3}}\right)+\alpha_{5} \ln \left(\frac{w_{1}}{w_{3}}\right) \ln \left(\frac{w_{2}}{w_{3}}\right) \\
& +\frac{1}{2} \alpha_{6}\left[\ln \left(\frac{w_{1}}{w_{3}}\right)\right]^{2}+\frac{1}{2} \alpha_{7}\left[\ln \left(\frac{w_{2}}{w_{3}}\right)\right]^{2}+\alpha_{8} \ln y \ln \left(\frac{w_{1}}{w_{3}}\right)+\alpha_{9} \ln y \ln \left(\frac{w_{2}}{w_{3}}\right)
\end{aligned}
$$


where $T C=$ Total cost cost, $y=$ output,$w_{1}=$ price of labour, $w_{2}=$ price of physical capital, $w_{3}$ = price of borrowed funds. Individual bank indices have been dropped for simple presentation.

The estimated coefficients of the cost function are then used in the calculation of the marginal cost. The marginal cost is equal to the product of the derivative of the logarithm of total cost to output.

$$
M C=\frac{T C}{y}\left[\alpha_{1}+\alpha_{2} \ln y+\alpha_{8} \ln \left(\frac{w_{1}}{w_{3}}\right)+\alpha_{9} \ln \left(\frac{w_{2}}{w_{3}}\right)\right]
$$

Bank level marginal cost $\left(\mathrm{mc}_{\mathrm{it}}\right)$ and corresponding output price, measured as total income divided by total bank assets $\left(\mathrm{P}_{\mathrm{it}}\right)$, are in turn used to calculate the bank-specific time-varying Lerner Index.

$$
\text { Lerner }_{i t}=\frac{\left[P_{i t}-M C_{i t}\right]}{P_{i t}}
$$

The index ranges between zero and one. Higher values imply greater market power. In a perfectly competitive industry the price is equal to marginal cost, giving a Lerner Index value of zero, indicating that firms have no market power. A bigger difference between price and marginal cost shows that there is greater monopoly power. Coccorese (2009) argued that there is room for the Lerner Index to be negative, since banks may choose as a consequence of predatory conduct or because of external factors, such as an economic crisis, to allow prices to go below the marginal cost, leading to negative mark-ups. Coccorese (2009) further argued that given that the index is calculated from observed and calculated information, the Lerner Index can be negative. Simpasa (2013) claimed that a negative Lerner Index could be evidence of superior competition.

The study ascertains the determinants of market power in the Zimbabwean banking sector by relating the Lerner Index to bank-specific and environmental factors (industry and macroeconomic variables). The study employs panel regression estimation techniques with the Lerner Index as the dependent variable. The study tests whether to use panel regression with fixed effects or random effects using the Hausman test. The determinants of competition are divided into three main categories, namely the internal determinants (bank size, non-performing loan ratio, capital adequacy, and return on assets); financial structure indicators (market share) and external economic indicators (economic growth and inflation). The choice of the variables is similar to previous works (Sanya and Gartner 2012; Simpasa 2013; Amidu \& Wilson 2014).

The model is expressed as follows:

$$
\begin{gathered}
L I_{t}=\alpha+\beta_{1} L N S I Z E_{t}+\beta_{2} N P L_{t}+\beta_{3} C A D E Q_{t}+\beta_{4} R O A_{t}+\beta_{5} G D P G_{t}+\beta_{6} I N F_{t} \\
+\beta_{7} M K T_{t}+\varepsilon_{t}
\end{gathered}
$$

where LNSIZE represents the size of the bank and is expected to have a positive impact on the Lerner Index. As a bank increases in size, it is expected to increase its muscle to underwrite more business, hence increasing its market power. NPL is a measure of credit risk measure as nonperforming loans as percentage of total loans. An increase in the non-performing assets increases the amount of non-productive resources, which reduces the bank's ability to underwrite more business. This then compromises the bank's market power. The variable is expected to have a negative effect on the market power of banks.

CADEP represents the capital adequacy ratio. Banks that are adequately capitalised have the ability to increase the amount of business they underwrite at the strength of their capital - hence to perform better than undercapitalised banks. The higher the ratio, the greater the market power. 
ROA represents the profitability of the banking institutions and is expected to have a positive impact on market power. GDPG measures the economic growth of the economy. It is expected that as the economy grows the market power of banks also increases. INF represents inflation rate and is expected to have a negative effect on market power. An inflationary environment makes planning difficult, and if unanticipated banks can incur losses, as it takes time for them to adjust their pricing accordingly. This then makes reduces the power of banks. MKT represents the market shares of the banks, which is expected to have a positive effect on market power. A banking institution with greater market share has the power to increase its prices as compared to those with smaller market shares, which can easily lose their market because of their small size.

The study employs quarterly data for the period 2009-2014. Data constraints restricted the authors from extending the study period to the period before 2009. The data for the period is not available on the banks' websites, since it was distorted due to the hyperinflation, and banks did not report their financial results for the period 2007-2008. A total of 18 banks constituted the sample with equal numbers of observations across the banks reflecting a balanced panel. The study relied on published financial statements (balance sheet and income statement) for banks and quarterly bank returns to the central bank as the main sources of data.

\section{RESULTS AND INTERPRETATION}

As a preliminary analysis, the statistical properties of the data are assessed using descriptive statistics, correlation analysis and unit root tests.

\subsection{Descriptive statistics}

TABLE 2 presents the descriptive statistics of the variables used in the study.

TABLE 2: Descriptive statistics

\begin{tabular}{|c|c|c|c|c|c|}
\hline & Mean & Median & Maxi & $\operatorname{Min}$ & Std. Dev \\
\hline CADEQ & 0.23 & 0.16 & 0.91 & 0.04 & 0.17 \\
\hline LNSIZE & 18.66 & 18.81 & 21.26 & 14.86 & 1.14 \\
\hline$N P L$ & 0.07 & 0.04 & 0.62 & 0.00 & 0.09 \\
\hline ROA & 0.04 & 0.02 & 0.15 & -0.03 & 0.06 \\
\hline MKT & 0.05 & 0.03 & 0.28 & 0.00 & 0.06 \\
\hline INF & 0.00 & 0.00 & 0.03 & -0.08 & 0.02 \\
\hline$G D P G$ & 0.08 & 0.08 & 0.12 & 0.03 & 0.04 \\
\hline Price of labour $\left(\boldsymbol{W}_{\mathbf{1}}\right)$ & 0.04 & 0.03 & 0.16 & 0.00 & 2.68 \\
\hline Price of fied capital $\left(\boldsymbol{W}_{2}\right)$ & 0.04 & 0.03 & 0.16 & 0.00 & 0.03 \\
\hline Price of funds $\left(\boldsymbol{W}_{3}\right)$ & 0.01 & 0.01 & 0.06 & -0.10 & 0.01 \\
\hline
\end{tabular}

Source: Authors' analysis 
The mean, maximum, minimum and the standard deviation of the variables under study are shown in TABLE 2. The variation of the data set is minimal, as reflected by the low standard deviations of the variables.

\subsection{Correlation matrix}

TABLE 3 shows the correlation matrix of the study variables.

TABLE 3: Correlation matrix

\begin{tabular}{|c|c|c|c|c|c|c|c|c|c|c|}
\hline & $C A D E Q$ & LNSIZE & $N P L$ & $R O A$ & $M K T$ & $W_{1}$ & $\boldsymbol{W}_{2}$ & $w_{3}$ & $I N F$ & $G D P G$ \\
\hline$C A D E Q$ & 1.000 & & & & & & & & & \\
\hline LNSIZE & -0.752 & 1.000 & & & & & & & & \\
\hline$N P L$ & -0.213 & 0.121 & 1.000 & & & & & & & \\
\hline$R O A$ & 0.064 & -0.288 & 0.170 & 1.000 & & & & & & \\
\hline$M K T$ & -0.503 & 0.698 & -0.131 & -0.309 & 1.000 & & & & & \\
\hline$W_{1}$ & -0.070 & 0.028 & 0.285 & 0.541 & -0.142 & 1.000 & & & & \\
\hline$W_{2}$, & 0.108 & -0.296 & 0.028 & 0.834 & -0.284 & 0.194 & 1.000 & & & \\
\hline$W_{3}$ & 0.036 & -0.284 & 0.118 & 0.211 & -0.268 & 0.073 & 0.080 & 1.000 & & \\
\hline INF & -0.246 & 0.238 & 0.031 & 0.079 & -0.011 & -0.010 & 0.118 & 0.096 & 1.000 & \\
\hline$G D P G$ & -0.360 & 0.446 & 0.189 & 0.104 & -0.003 & 0.222 & 0.058 & -0.038 & 0.324 & 1.000 \\
\hline
\end{tabular}

Source: Authors' analysis

The variables under study do not show strong correlation among themselves (TABLE 2). Gujarati (2007) argued that the problem of multi-collinearity exists if the correlation between independent variables is above 0.8 . All the correlation coefficients between the independent variables were less than 0.8 .

TABLE 4: Results for unit root test

\begin{tabular}{cccc}
\hline Variable & Statistic & P-Value & Level of Stationarity \\
\hline CADEQ & 12.2361 & 0.0000 & $\mathrm{I}(0)$ \\
$\boldsymbol{L N S I Z E}$ & 13.6395 & 0.0000 & $\mathrm{I}(0)$ \\
$\boldsymbol{N P \boldsymbol { L }}$ & 9.5185 & 0.0000 & $\mathrm{I}(0)$ \\
$\boldsymbol{R O A}$ & 15.6462 & 0.0000 & $\mathrm{I}(0)$ \\
$\boldsymbol{M} \boldsymbol{K} \boldsymbol{T}$ & 2.6697 & 0.0038 & $\mathrm{I}(0)$ \\
$\boldsymbol{W}_{\mathbf{1}}$ & 7.6487 & 0.0000 & $\mathrm{I}(0)$ \\
$\boldsymbol{W}_{\mathbf{2},}$ & 10.8129 & 0.0000 & $\mathrm{I}(0)$ \\
$\boldsymbol{W}_{\mathbf{3},}$ & 7.9725 & 0.0000 & $\mathrm{I}(0)$ \\
\hline
\end{tabular}




\begin{tabular}{cccc}
\hline Variable & Statistic & P-Value & Level of Stationarity \\
\hline Macro data & & & \\
INF & 8.9940 & 0.0000 & $\mathrm{I}(0)$ \\
GDPG & 5.7977 & 0.0000 & $\mathrm{I}(1)$ \\
\hline
\end{tabular}

Source: Authors' analysis

The results of the unit root test are shown in TABLE 4. Levin, Lin and Chu t unit root tests were used to test the stationarity of the micro panel data. All the bank level data were found to be stationary in their levels. The unit root test for the macroeconomic data of inflation and GDP were tested using the augmented Dickey Fuller test. Inflation was stationary in its levels, while the economic growth series was stationary after first differencing.

\subsection{Estimation of cost function}

The estimation results and their interpretation are presented in this section. Regression results for the cost function specified in equation 1 are shown in TABLE 5 .

TABLE 5: Estimating the translog cost function

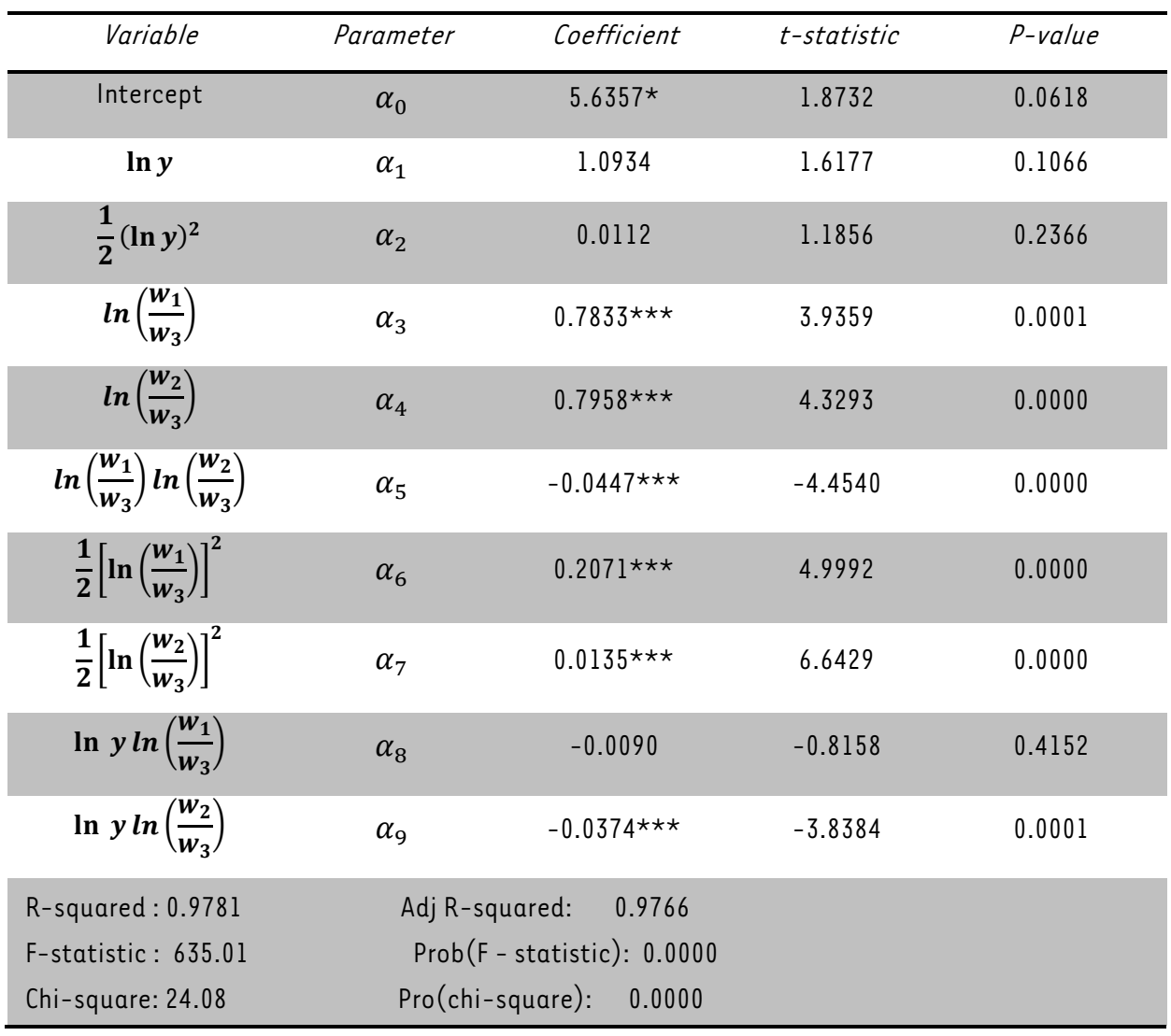

Source: Authors' analysis 
The results in TABLE 4 were estimated using the fixed effects model, since the Hausman specification tests for panel data ruled out the random effects model. The results further show that the model is properly specified as depicted by the F-statistic with probability of zero.

The results indicate that total costs are explained by the prices of the factors of production. The model, as measured by the R-squared, predicted that $98 \%$ of the variation in the total cost is explained by the independent prices of factors of production. The results from the estimation of the translog cost function are used in estimating the marginal costs which were used to derive the Lerner Index.

The average Lerner Index for the period 2009-2014 was 0.07, depicting neither monopoly nor perfect competition. This implies that the Zimbabwean banking sector over the period operated under monopolistic competition. This means that banks enjoyed some market power during the study period.

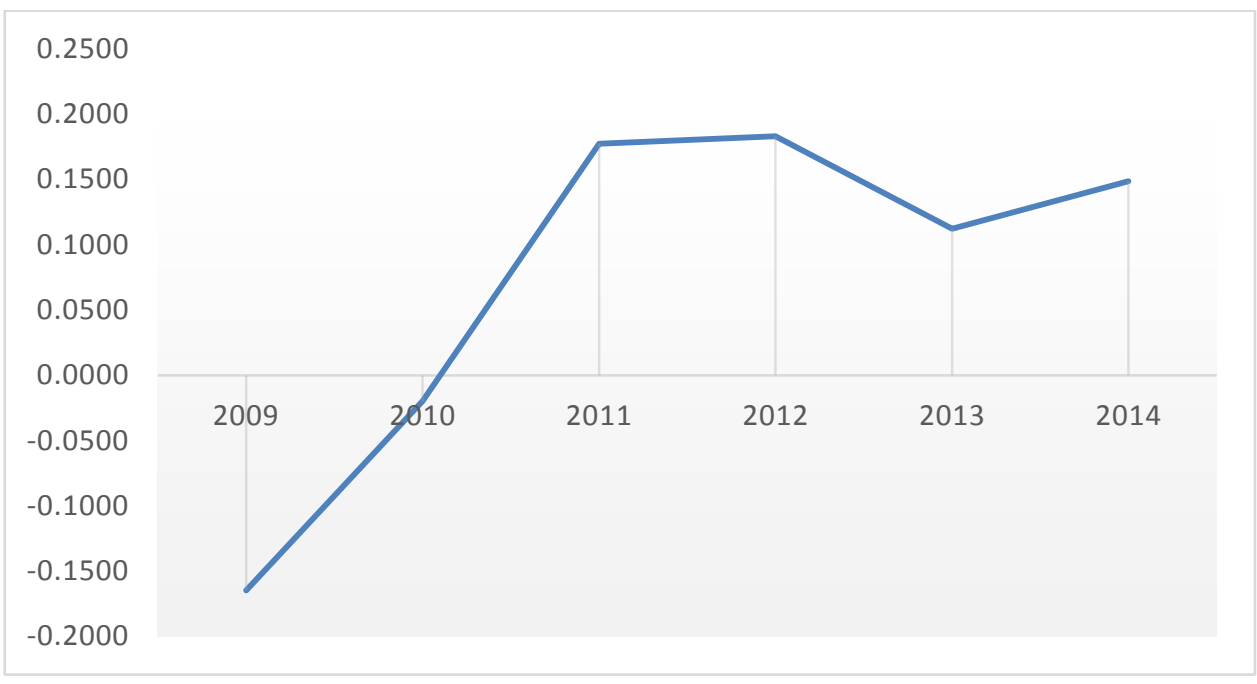

\section{FIGURE 3: Evolution of Lerner Index}

Source: Authors' analysis

The Lerner Index increased during the period 2009-2014, showing an increase in market power during the period (FIGURE 3). Despite the general increase in market power during the period, the increase exhibited some ups and downs. FIGURE 1 indicates that the Lerner Index was negative for the years 2009 and 2010. The period 2009-2010 resembles the post-crisis period, where the majority of banks had suffered deposit flight and only a few banks commanded the greatest market share. In 2008 about $97 \%$ of the market share was held by the top four banks, leaving only $3 \%$ to the majority of players. Banks had to compete to grab some market share. This fostered intense competition among banks. Most of the banks offered loans to attract deposits. Simpasa (2013) also found the same negative result in the Zambian market during the period 2010-2011 after the financial crisis. The Lerner Index increased between 2009 and 2011 . This means that the market power of all banks combined increased during the period 2009-2011. Banks were using their individual market power to increase the price of the banking products. As a result of the monopolistic market structure the banks were able to individually increase the pricing of their unique products. This coincided with the growth in the economy, which allowed banks to increase prices as the demand for the banking products also increased. As the economy started to falter, 
with economic growth rate declining, the market power of banks also declined. The Lerner Index declined between 2011 and 2013. The market power to price became constrained as the economy started to decline and the amount of non-performing loans started to increase. Banks became strict, screening clients in order to avoid risky clients, hence they had to lend at lower rates to these clients because of their low risk profile. The pricing power of banks was further reduced with the memorandum of understanding.

\subsection{Determinants of market power}

This section examines the determinants of market power in the banking sector. Using the estimated Lerner Index the study established the determinants of market power for the period 2009-2014. The regression results for estimating the determinants of market power are shown in TABLE 6.

The Hausman specification test retained a chi-square of 19.44 with the probability of 0.0006 , suggesting that the fixed effects model gives the best fit. The model retained an R-squared of $37 \%$ implying that $37 \%$ of the variation in market power is explained by the variation in the independent variables. The result suggests that the ability of the banks to price their products above the marginal cost is determined by the bank-specific, industry-specific and macroeconomic economic factors.

TABLE 6: Determinants of market power

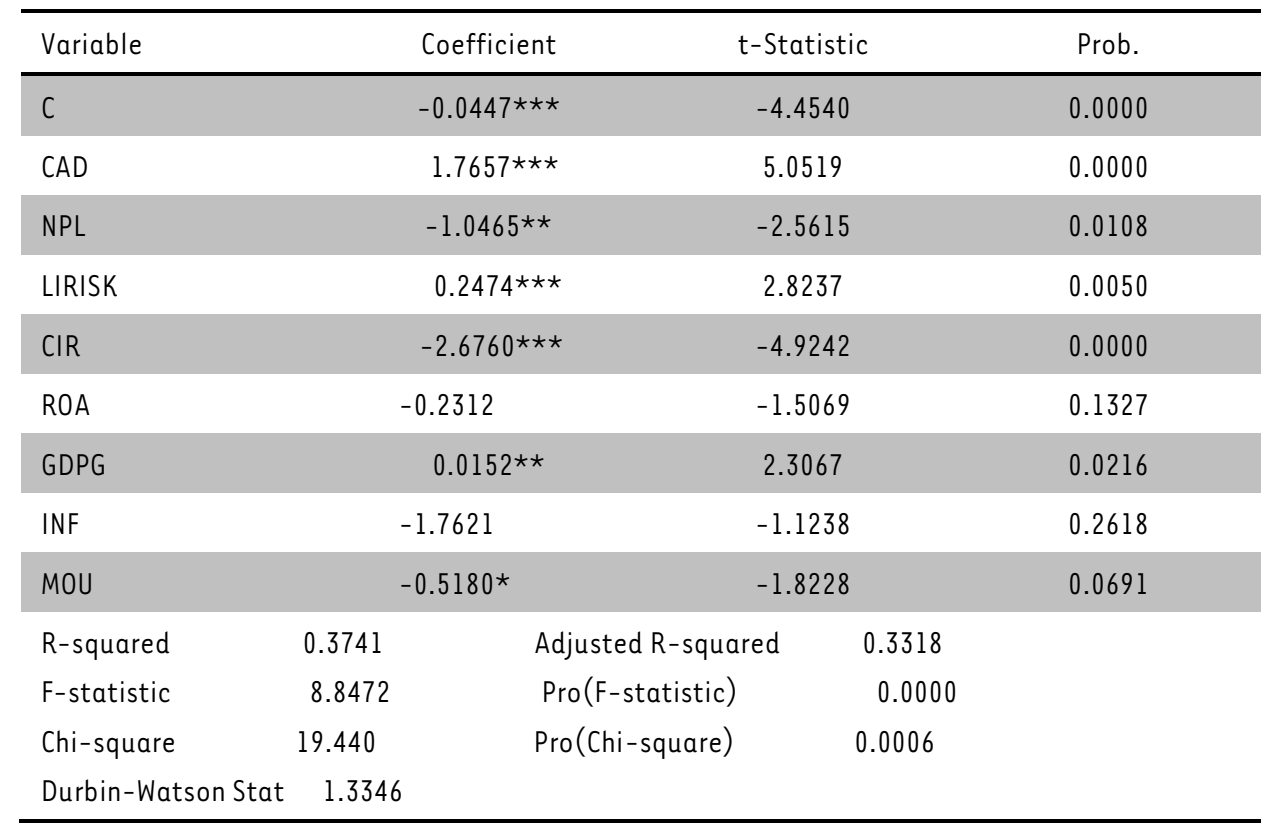

Source: Authors' analysis

Capital adequacy has a positive effect on market power. This implies that a banking sector that is adequately capitalised has power to price products above the marginal cost. In other words, capital adequacy increases the ability of firms to price their products above their marginal cost. Highly capitalised banks have higher market power, which may reflect the fact that such banks 
pay less for deposits, as depositors consider these banks to be more secure. Adequate capitalisation enhances the liquidity and solvency of the banks. Inadequate capitalisation has the reverse effect, as it reduces the market power of banks.

The results depict a negative relationship between non-performing loans and market power. The results mean that an increase in non-performing loans reduces the market power of the bank. Deterioration in the loan book of a bank reduces the income of the bank. The deterioration in the loan book was caused by higher interest rates on loans. Once banks identify that loans are deteriorating, they are supposed to reduce the price of loans or cut down on lending. Under such circumstances there is increased competition for quality clients whose risk profile is low, and who hence are charged lower interest rates. This implies that an increase in non-performing loans leads to reduction of pricing power of banks. The results therefore mean that an increase in nonperforming loans could lead banks to compete for good clients. NPLs reached $20.1 \%$ in 2014 . The result compares well with the study by Simpasa (2010), who found that the credit risk variable has a negative and significant effect on market power in Zambia.

Liquidity risk has a positive impact on market power. Liquidity risk is the risk of loss to a bank resulting from its inability to meet its needs for cash or from inadequate liquidity levels, which must be covered by funds obtained at excessive cost. The result means that as the bank increases its liquidity risk its market power also increases. This arises from the fact that the higher the risk the higher the return, which forces the banks to increase their liquidity risk. As a bank borrows costly resources it depends on its ability to price the funds at a higher price than the actual cost of the funds. Liquidity risk as a factor may arise from the possible inability of a bank to accommodate decrease in liabilities, since it becomes hard to raise funds for increasing demand for loans. Zimbabwe banks were forced to increase their liquidity risk as a result of increased demand. This led to the situation where the loan to deposit ratio increased to above $100 \%$, meaning the banks' ability to honour their liabilities in the event of a shock was compromised. Under such circumstances banks increased the price of funds, adding a premium reflecting the liquidity risk encountered.

The cost-income ratio has a negative effect on market power. An increase in the cost-income ratio means a decline in management efficiency in containing costs. The results mean that a decline in management efficiency leads to an increase in market power. This means that as banks' ability to contain cost declined, they were forced to increase their pricing in order to cover their inefficiencies. The higher interest rates were meant to cover the higher cost of raising income. The higher interest rate spreads that were recorded in Zimbabwe during the period 2009-2014 were a reflection of management inefficiencies, which forced the authorities to intervene through the introduction of the memorandum of understanding.

Economic growth has a positive impact on market power. The growth in the economy was a catalyst for the banks to increase their pricing power. This was motivated by the increased demand for banking products that accompanied the growth in the economy. Both individuals and firms increased their demand for the loans and advances. Banks increased their prices, since demand was greater than supply.

The memorandum of understanding had a negative effect on market power. The introduction of the MoU reduced the market power of banks. The pricing of banking products was predefined through the MoU, hence restricting banks from increasing interest rates and bank charges above certain thresholds. When the MoU was introduced most banks had to cut down on their prices so as to be compliant with the regulatory requirement on bank charges and interest rates. Those banks that were already charging below the stipulated thresholds were prohibited from increasing 
the interest rates and charges. This conforms to the result that the pricing power of the banks was reduced by the MoU. Banks were therefore forced to compete on non-price bases as is consistent with the perfect competition market structure and monopolistic competition to a certain extent.

\section{CONCLUSION}

The study has shown that the banking sector operated under monopolistic competition during the period 2009-2014. The result means that banking institutions possess some market power. This arises from the fact that banks sell products which are substitutes but carrying differentiation in terms of advertising and branding, among other attributes. This makes each bank's product unique, giving the bank some market power in pricing the product. The market power is diminished by the availability of close substitutes.

The study has shown that competition is explained by capital adequacy, non-performing loans, liquidity risk, cost-income ratio, economic growth, and regulatory interventions. The memorandum of understanding that was signed between the central bank and banks had a negative effect on market power. The results mean that the level of competition in the banking sector is determined by both internal and external factors. The results imply that both bank managers and policymakers have a role to play in enhancing competition in the banking sector. Internally, there is need for bank managers to put in place measures that enhance credit risk management, improve the capitalisation of the bank, and improve liquidity risk management.

Policymakers should ensure that they put in place measures that increase economic activity in the country. An increase in economic activity increases the demand for banking products. On the other hand, the study has shown that the memorandum of understanding that was put in place by the government reduced the market power of the banks. This curtailed the pricing power that banks had, as the MoU predefined the pricing formula for the banking products. In other words, bank charges and interest rates were dictated by the MoU.

\section{LIST OF REFERENCES}

Abdul Majid, M.Z. \& Sufian, F. (2008). Market structure and competition in emerging market: Evidence from Malaysian Islamic Banking Industry, MPRA Paper, No. 12126.

Amidu, M \& Wilson, J. O. S. (2014). Competition in African Banking: Do Globalization and Institutional Quality Matter? Available at SSRN.

Anzoátegui D., Martínez-Pería, M.S. \& Melecky, M. (2012). Bank competition in Russia: An examination at different levels of aggregation. Emerging Markets Review, 13(1):42-57.

Berger, A. \& Hannan, T. (1989). The Price-Concentration Relationship in Banking. The Review of Economics and Statistics, 71(2):291-299.

Berger, A.N., Klapper, L.F., \& Turk-Ariss, R. (2009). Bank competition and financial stability. Journa/ of Financial Services Research, 35: 99-118.

Boone, J. (2000) Competition. CEPR Discussion Paper Series No. 2636, December.

Boone, J. (2001) Intensity of competition and the incentive to innovate. International Journal of Industrial Organization, 19:705-726. 
Bresnahan, T.F. (1982). The oligopoly solution concept is identified, Economic Letters, 10:87-92.

Chipika, J.T. \& Malaba, J. (2011). Indigenisation and economic empowerment study. Harare, Zimbabwe: Business Council of Zimbabwe.

Claessens, S. \& Laeven, L. (2004). What drives bank competition? Some international evidence? Journal of Money, Credit, and Banking, 36: 562-583.

Claessens, S. (2009). Competition in the financial sector: Overview of competition policies. IMF WP $09 / 45$

Coccorese, P. (2009). Market power in local banking monopolies. Journal of Banking \& Finance. Elsevier, 33(70):1196-1210.

Delis, M. (2012). Bank competition, financial reform and institution. The importance of being developed economies, 97(2):450-65.

Delis, M.D., Staikouras, K.C. \& Varlagas, P.T. (2008). On the measurement of market power in the banking industry. Journal of Business Finance and Accounting, 35:1023-1047.

Demirgüç-Kunt, A. \& Peria, M.S.M. (2010). A framework for analyzing competition in the banking sector: an application to the case of Jordan. Policy Research Working Paper Series, No. 5499. The World Bank.

Demirgüç-Kunt, A., Laeven, L. \& Levine, R. (2004). Regulations, market structure, institutions, and the cost of financial intermediation. Journal of Money, Credit and Banking, 36(2):593-622.

Fernández de Guevara, J. \& Maudos, J. (2007). Explanatory variables of market power in the banking system. Manchester School, 75(3):275-296.

Fernández de Guevara, J., Maudos, J. \& Pérez, F. (2005). Market power in European banking. Journal of Financial Services Research, 27:109-137.

Fu, X.M. \& Heffernan, S. (2009). The effects of reform on China's bank structure and performance. Journal of Banking and Finance, 33:39-52.

Fungacova, Z. \& Weill, L. (2009). How market power influences bank failures: Evidence from Russia, Bank of Finland, BOFIT Institute for Economies in Transition. Discussion paper 12

Fungacova, Z., Solanko, L. \& Weill, L. (2010). Market power in the Russian banking industry. Bank of Finland (BOFIT) Discussion Paper, No. 3/2010.

Gelos, G. \& Roldos, J. (2004). Consolidation and market structure in emerging market systems. Emerging Markets Review, 5:39-59.

Guzman, M. (2000). Bank structure, capital accumulation, and growth: A simple macroeconomic model. Economic Theory, 16(2):421-455.

Hasan, I. \& Marton, K. (2003). Development and efficiency of the banking sector in a transitional economy: Hungarian experience. Journal of Banking and Finance, 27(7):2249-2271.

Hicks, J. (1935). Annual survey of economic theory: The theory of monopoly. Econometrica, 3:1-20.

Jiménez, G., Lopez, J., \& Saurina, J. (2010). How does competition impact on bank risk taking? Banco De Espana, Working Paper 1005.

Kanyenze, G., Kondo, T., Chitambara, P. \& Martens, J. 2011. Beyond the enclave: Towards a pro-poor and inclusive development strategy. Harare, Zimbabwe: Weaver Press. 
Korsah, K., Nyarko, E.K. \& Tagoe, N.A. (2001). Impact of financial sector liberalization on competition and efficiency in the Ghanaian banking industry. International Labor Organization Research paper, 01-2: 1-51.

Lau, L., (1982) On Identifying the Degree of Competitiveness from Industry Price and Output Data. Economics Letters, 10:93-99.

Leon, F. (2014). Measuring competition in banking: A critical review of methods. CERDI etudes et documents, 12:1-44

Lerner, A.P. (1934). The concept of monopoly and the measurement of monopoly power. The Review of Economic Studies, 1:157-175.

Liu, J.S., Lu, L.Y.Y., Lu, W. \& Liu, B.J.Y. (2010). Data envelopment analysis 1978-2010: A citation-based literature survey. Elsevier.

Mabika, S.E. 2001. Monetary Policy Framework in Zimbabwe. International Conference on Monetary Policy Frameworks in Africa.

Makoni, T.A. 2010. Overview of Zimbabwean Banking Sector. Available:

http://EzineArticles.com/?expert=Dr_Tawafadza_A_Makoni [Accessed 14 December 2014).

Mumvuma, T., Mujajati, C. \& Mufute, B. 2001. Understanding reform: The case of Zimbabwe. Global Development Network.

Pagano, M. (1993). Financial markets and growth. An overview. European Economic Review, 37:613622.

Panzar, J.C. \& Rosse, J.N. (1982). Structure, Conduct and Comparative Statistics. Bell Laboratories Economic discussion paper.

Panzar, J.C. \& Rosse, J.N. (1987). Testing for monopoly equilibrium. Journal of Industrial Economics, 35:443-456.

Pruteanu-Podpiera, A.M. (2007). The role of banks in the Czech monetary policy transmission mechanism, Economics of Transition, 15(2):393-428.

Reserve bank of Zimbabwe 2009. Harare, Zimbabwe: Bank Annual Report.

Reserve bank of Zimbabwe 2009. Harare, Zimbabwe: Monetary Policy Statements.

Reserve bank of Zimbabwe 2014. Harare, Zimbabwe: Bank Annual Report.

Reserve bank of Zimbabwe 2014. Harare, Zimbabwe: Monetary Policy Statements.

Sanya, S. \& Gartner, M. (2012). Competition in the EAC banking system. IMF Working Paper 12/32

Simpasa, A.M. (2013). Competition and market structure in the Zambian banking sector. African Development Bank Group. Working Paper Series, No.168. 